\title{
The Cost-effectiveness of Improving Indoor Air Ventilation for the Prevention of Covid-19 in Commercial Spaces
}

\section{Zafar Zafari ( $\nabla$ zzafari@rx.umaryland.edu )}

University of Maryland https://orcid.org/0000-0003-2507-4949

Pedro M. de Oliveira

University of Cambridge

Savvas Gkantonas

University of Cambridge

Chinenye Ezeh

Columbia University Mailman School of Public Health

Peter Alexander Muennig

Columbia University Mailman School of Public Health

\section{Research}

Keywords: Economic evaluation, improving ventilation, Covid-19, SARS-CoV-2, commercial spaces, restaurants and bars, prevention strategies

Posted Date: October 25th, 2021

DOl: https://doi.org/10.21203/rs.3.rs-986089/v1

License: (c) (1) This work is licensed under a Creative Commons Attribution 4.0 International License. Read Full License 


\section{Abstract}

Objective: Airborne infection from aerosolized SARS-CoV-2 poses an economic challenge for the large number of small businesses without existing heating, ventilation, and air conditioning (HVAC) systems. Standalone units have been recommended, but are costly and may not achieve adequate air exchange to prevent infection.

Study design: Cost-effectiveness analysis with Monte Carlo simulation.

Methods: We built a probabilistic decision-analytic model in a Monte Carlo simulation that examines aerosol transmission of SARS-CoV-2 in an indoor space. As a case study, we modeled a poorly ventilated indoor restaurant. We evaluated the cost-effectiveness of improving ventilation rate to 12 air changes per hour $(\mathrm{ACH})$, the equivalent of hospital-grade filtration systems used in emergency departments. Our basecase scenario assumes that the mean year-round prevalence of actively infectious cases in the community surrounding the restaurant is $1 \%$, and that $50 \%$ of patrons were fully vaccinated. Our bestcase scenario assumes a community prevalence of $0.1 \%$ and $70 \%$ of patrons vaccinated, and our worstcase scenario assumes a community prevalence of $2 \%$ and $0 \%$ of patrons vaccinated. We also provide a customizable online tool.

Results: All 3 scenarios resulted in a net cost-savings and infections averted. For the base-case scenario, improving ventilation to $12 \mathrm{ACH}$ was associated with 33 (95\% Credible Interval [Crl]: 18-50) aerosol infections averted over one year, producing an estimated cost savings of $-\$ 97,467$ (95\% Crl: $-\$ 156,760$, $-\$ 50,877)$ and $0.84(95 \%$ Crl: $0.46,1.40)$ quality-adjusted life years (QALYs) gained.

Conclusions: It is cost-effective to improve indoor ventilation in small businesses in older buildings that lack HVAC systems during the pandemic.

\section{Introduction}

SARS-CoV-2 may be transmitted person-to-person via exhaled respiratory aerosols that accumulate within poorly ventilated spaces $(1-5)$. Airborne transmission of SARS-CoV-2 therefore poses major public health and economic challenges as commercial spaces re-open (3). To meet this challenge, newer commercial spaces can upgrade existing heating, ventilation, and air conditioning (HVAC) systems (6-9). One standard is 12 air exchanges per hour, the recommended ventilation for emergency department waiting rooms (10).

However, older buildings tend not to have HVAC systems installed. When HVAC systems are not present, the Environmental Protection Agency (EPA) recommends alternative means of disinfecting the air (11). These may include standalone filtration systems containing high efficiency particulate air (HEPA) or electrostatic units, which filter particles down to the sub-micrometer size (11). However, standalone units are not designed for high-volume air filtration, and the size and quantity of such units to achieve $12 \mathrm{ACH}$ 
may not be practical. This is particularly true in poorly ventilated bars, cafes, and restaurants because customers intermingle without face coverings $(12,13)$.

Given that standalone units may be only marginally effective and are relatively expensive, we evaluated their cost-effectiveness. In this paper, we provide data for an example setting (a poorly ventilated restaurant), but our online model can be modified for any scenario.

\section{Methods}

We built a decision-analytic model that is designed to assist local and federal regulators in setting standards for improving the air handling systems in poorly ventilated indoor commercial spaces for the prevention of SARS-CoV-2 infections via aerosolized particles. The model is designed to compute the incremental cost-effectiveness ratio (ICER), which is the net cost of an intervention divided by the number of quality-adjusted life years (QALYs) gained (14). The ICER can be used to compare commonly deployed health or medical interventions to assess whether they are affordable $(15,16)$. We followed guidelines for conducting our cost-effectiveness analyses (17), including estimation of costs from a societal perspective. We based our analysis on a standardized space for the purposes of this paper but provide an online interface for customization to most spaces.

Characteristics of the standardized space: Each restaurant, café, or bar is unique with respect to the size, number of customers, hours of operation, and the time that customers spend in the establishment. This variation presents challenges for understanding the airflow and filtration needs for any given business. For this reason, we developed a customizable interface that allows both regulators and restaurant owners to obtain estimates for a range of settings

(https://openupuniversities.shinyapps.io/Airborne_Transmission_Covid19/). In this paper, we used a small, poorly ventilated restaurant space as an example so that the reader can get a general idea of the cost-effectiveness of standalone ventillation.

The standardized restaurant was open for a total of 3 hours for lunch service and 6 hours for dinner service. We assumed that the restaurant has a seating capacity of 30 occupants in a 1,000 square foot space and a ceiling height of 9 feet, and that each occupant is seated for one-hour at lunch and 1.5-hours during dinner. The model assumptions are listed in Table 1. 
Table 1

Model assumptions for evaluating the cost-effectiveness of improving ventilation in commercial spaces for the prevention of SARS-CoV-2.

\section{Assumptions}

The standardized room of 1000 square-foot with a ceiling height of 9 feet has 0.8 air changes per hour, primarily from the door opening and closing and the food vent running.

For lunch, the restaurant is open for 3 hours. Each of 30 occupants is seated for one hour. We modeled 3 consecutive lunch events each for a duration of 1 hour. In each event, the restaurant is at the full seating capacity.

For dinner, the restaurant is open for 6 hours. Each of 30 occupants is seated for 1.5 hours. We modeled 4 consecutive dinner events each for a duration of 1.5 hours. In each event, the restaurant is at the full seating capacity.

Between lunch and dinner hours, the restaurant is closed for enough time so that the virus concentration in the indoor air dropped to zero as workers opened doors and moved throughout the space.

The restaurant is operating 7 days a week with similar lunch and dinner hours.

The model is built under well-mixed conditions for an infected individual present in an indoor space and there is dynamic airflow in unpredictable patterns associated with the movement of people and an overhead fan $(18,19)$.

We assumed that transmission through the close-range mode-that is, when infectious aerosols were inhaled directly from the exhaled breath of an infected individual by a susceptible person in its vicinity -is on par between the comparison arms. Thus, only infection through the inhalation of accumulated aerosols, often referred to as the long-range mode of airborne transmission, is modeled and closerange transmission is not modeled $(18,19)$.

We assumed that infected symptomatic Covid-19 cases would quarantine for 14 days. We also assumed those infected cases who required hospitalizations would quarantine for 21 days.

All wages were valued at the median hourly wage in the US (14).

US: United States.

Temporal evolution of concentration of viable viral copies in an indoor space: In a previous published work, two co-authors developed a model (18) and online tool (19) for the temporal concentration of aerosolized viral copies in the air under well-mixed conditions for an infected individual present in an indoor space. The model considers the evaporation and settling of virus-laden droplets of various sizes exhaled by an infected individual in terms of plaque forming units (PFUs). These are evaluated from a combination of reduced-order modeling and previous experimental measurements. The details are described elsewhere (18). In brief, the concentration of PFUs dispelled by an infected person in an indoor space can be shown as

$C(t)=n_{i n f} \cdot \frac{N_{g e n}}{V \cdot(\lambda+\kappa+\nu)}+\left(C\left(t_{0}\right)-n_{i n f} \cdot \frac{N_{g e n}}{V \cdot(\lambda+\kappa+\nu)}\right) \cdot \exp \left(-(\lambda+\kappa+\nu) \cdot\left(t-t_{0}\right)\right)$, where: 
$C(t)$ : concentration of viral PFUs over time and $C\left(t_{0}\right)$ represents the concentration at baseline;

$n_{\text {inf }}:$ number of infected individuals in the room;

$N_{\text {gen }}$ : generating factor for viral particles emitted by continuous exhalation of the infected person while speaking per time unit. The generating factor of $0.059 \mathrm{PFU} /$ second (18) was estimated using a viral load at the sputum of the infected person of $10^{\wedge} 10$ virus RNA copies $/ \mathrm{ml}$. While the mean virus RNA copies $/ \mathrm{ml}$ of the infected sputum for the original strains of Covid-19 was estimated as $7{ }^{\star} 10^{\wedge} 6(20)$, the emerging evidence shows that the number of viral copies is almost 1,000 times larger for the Delta variant (21), the most common Covid-19 strain at the time of publication. Therefore, to be conservative, we assumed a $10^{\wedge} 10$ virus RNA copies/ml for the Delta variant. We then applied a conversion factor of 0.01 to estimate PFUs (infectious units) from RNA copies (18). Here, the aerosol cut-off diameter-the size below which particles are carried by the ventilation air flow-was assumed to be $20 \mu \mathrm{m}$. The exhalation flow rate was assumed to be 0.211 liters/second representing a sedentary activity (18);

$V$ : Volume of the room. We showed our analysis for a $1000 \mathrm{ft}^{2}$ restaurant area size with a ceiling height of $9 \mathrm{ft}$;

$\lambda$ : Natural viral decay rate. An exponential decay at a rate of 0.636 per hour was assumed (22);

$\kappa:$ Settling rate of aerosols by gravity. A value of 0.39 per hour was assumed (18); and

$\nu:$ ventilation rate of the room per air changes per hours $(\mathrm{ACH})$.

Risk of infection in an indoor space through long-range transmission of airborne, aerosolized SARS-CoV-2 particles: For an average susceptible individual sitting in the restaurant, we calculated the risk of SARSCoV-2 infection based on the number of viral PFUs that the individual is exposed to for the duration of a lunch event ( 1 hour) or a dinner event (1.5 hours). A susceptible individual is defined as a person who is disease-free at the start of lunch or dinner service and is at risk of contracting the disease while sitting in the restaurant. We assumed that if people are sitting in the restaurant for an event, based on the prevalence of disease in the surrounding community (denoted by ), there would be, on average, infected individuals and susceptible individuals for that event. We calculated the number of PFU units that a susceptible individual is exposed to during an event (denoted by ) as follows

$n P F U_{\text {exposed }}=\int_{t_{1}}^{t_{2}} N . \operatorname{Pr} . C_{P F U}(t)$. Inhalation_rate. $d t$, where:

$t_{1}$ and $t_{2}$ :represents respectively the starting and ending time of the event;

$N . \operatorname{Pr}:$ represent the average number of infected people in the event;

$C_{P F U}(t)$ : represents the temporal concentration of viral PFU units (see the section "Temporal evolution of concentration of viable viral copies"); and 
Inhalation_rate : Inhalation rate of 0.521 liters/second for an average person with a sedentary activity person (e.g., sitting and speaking) (23).

We calculated the risk of infection (denoted by $p_{\text {inf }}$ ) for an average individual based on the number of viral PFUs the individual is exposed to during an event as follows:

$$
p_{\text {inf }}=1-\left(1-p_{d}\right)^{n P F U_{\text {exposed }}}
$$

where $p_{d}$ represents the probability of infection per exposure to one viral PFU. We calculated $p_{d}$ as 0.0024 (95\% Confidence Interval [CI]: 0.0013-0.0053) based on an infectious dose 50 (ID50) of 280 (95\% Cl: 130-530) PFUs $(18,24)$. The ID50 indicates the number of viral particles required to cause infection in $50 \%$ of the individuals exposed to these particles.

The above modeling approach considers only infection through the inhalation of accumulated aerosols, often referred to as the "long-range" mode of airborne transmission. Thus, transmission through the close-range mode-that is, when infectious aerosols were inhaled directly from the exhaled breath of an infected individual by a susceptible person in its vicinity-was assumed to be on par between the comparison arms and was disregarded.

Costs: We modeled the cost of installing standalone air filtration units with HEPA filters, which trap ultrafine particles down to the sub-micrometer size (11). Based on the restaurant's size and cubic feet per minute (CFM) airflow of the standalone units, we calculated the number of units required to produce the equivalent of $12 \mathrm{ACH}$ in the room. These units were assumed to be uniformly installed in the room to create different points of air disturbance.

We modeled direct and indirect costs of hospitalizations due to Covid-19 $(25,26)$. For indirect costs of hospitalizations, we assumed a 21-day absence from work spanning the time spent in the hospital time spent at home after hospital discharge. We assumed 8 hours of work lost per day at a value of $\$ 25 /$ hour (27). We assumed a 14-day quarantine for symptomatic infections for lost productivity and leisure time of 8 hours per day. Future values were discounted at $3 \%(14,17)$. All costs were adjusted to 2020 US dollars (Table 2). 
Table 2

Model input parameters for evaluating the cost-effectiveness of improving ventilation in commercial spaces for the prevention of SARS-CoV-2.

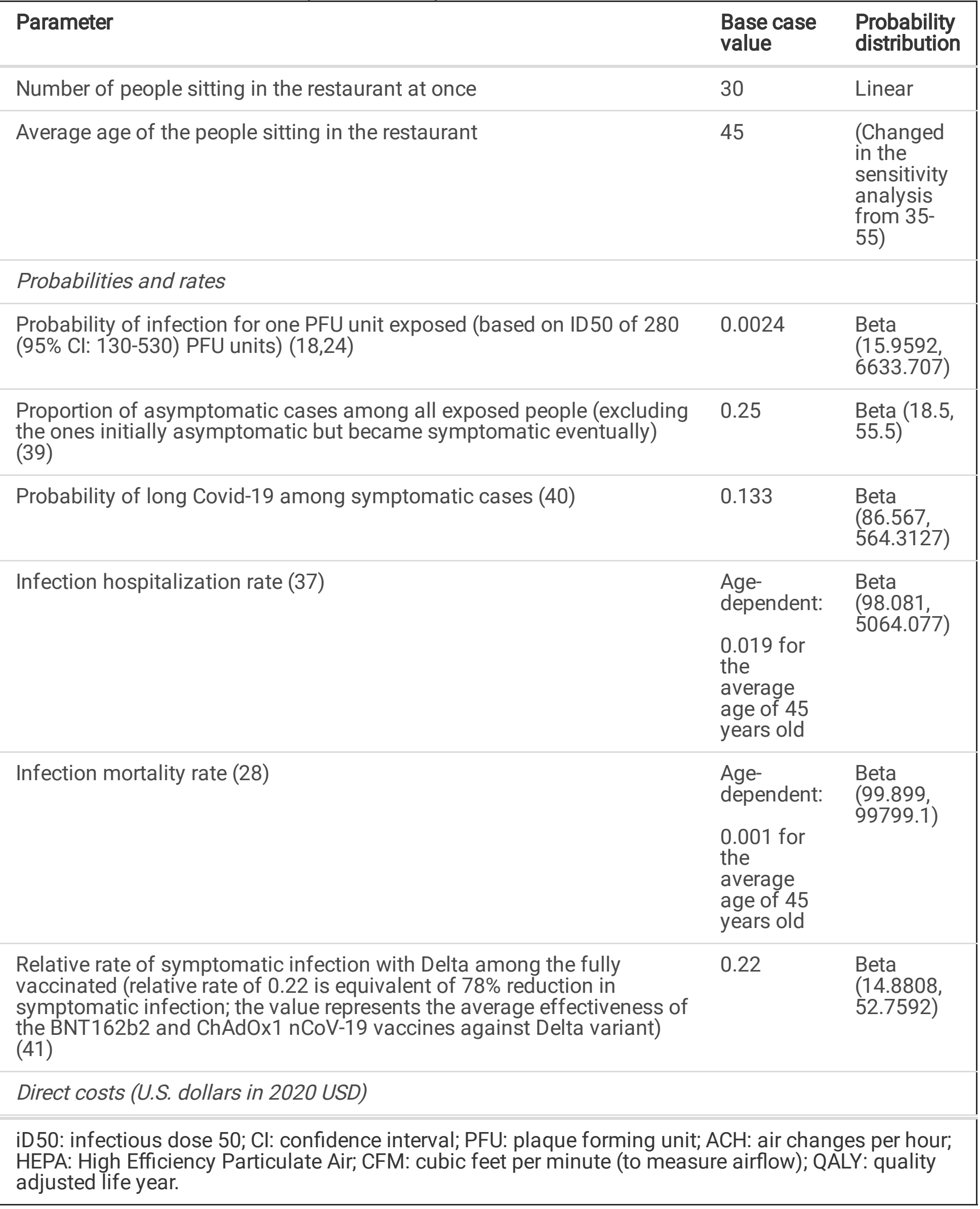




\begin{tabular}{|c|c|c|}
\hline Parameter & $\begin{array}{l}\text { Base case } \\
\text { value }\end{array}$ & $\begin{array}{l}\text { Probability } \\
\text { distribution }\end{array}$ \\
\hline $\begin{array}{l}\text { Improving room ventilation rate to } 12 \mathrm{ACH} \text { (by installing } 5 \text { standalone air } \\
\text { filtration units with HEPA filters trapping ultrafine particles down to the } \\
\text { sub-micrometer size that are uniformly installed in the room and } \\
\text { produce an equivalence of } 12 \mathrm{ACH} \text { for a } 1000 \mathrm{ft}^{2} \text { space (each unit } \\
\text { produces an airflow of } 347 \mathrm{CFM} \text { and costs } \$ 750 \text { ) (42) }\end{array}$ & $\$ 3,750$ & $\begin{array}{l}\text { Gamma } \\
(100 \\
0.02667)\end{array}$ \\
\hline Covid-19 hospitalization $(25,26)$ & $\$ 23,489$ & $\begin{array}{l}\text { Gamma } \\
(100 \\
0.00426)\end{array}$ \\
\hline \multicolumn{3}{|l|}{ Indirect costs (U.S. dollars in 2020 USD) } \\
\hline $\begin{array}{l}\text { Covid- } 19 \text { infection without hospitalization for symptomatic cases } \\
\text { (losses of productivity over } 2 \text { weeks of self-isolation) }\end{array}$ & $\$ 2,800$ & $\begin{array}{l}\text { Gamma } \\
(100 \\
0.036)\end{array}$ \\
\hline Covid-19 hospitalization (losses of productivity over 3 weeks) & $\$ 4,200$ & $\begin{array}{l}\text { Gamma } \\
(100 \\
0.024)\end{array}$ \\
\hline $\begin{array}{l}\text { Premature mortality due to Covid- } 19 \text { (calculating losses of annual } \\
\text { average wage of } \$ 50,000 / y e a r \text { beyond the age at death of } 45 \text { years old } \\
\text { in the base case model until the age of } 65 \text { years; future values were } \\
\text { discounted at } 3 \% \text { ) }\end{array}$ & $\$ 793,874$ & $\begin{array}{l}\text { Gamma } \\
(100 \\
0.000126)\end{array}$ \\
\hline \multicolumn{3}{|l|}{ Health-related quality of life } \\
\hline Losses of QALYs associated with a Covid-19 symptomatic case (28) & 0.008 & $\begin{array}{l}\text { Beta } \\
(99.192 \\
12299.81)\end{array}$ \\
\hline Losses of QALYs associated with a long Covid-19 infection (28) & 0.034 & $\begin{array}{l}\text { Beta } \\
(96.566, \\
2743.61)\end{array}$ \\
\hline Losses of QALYs associated with a Covid-19 hospitalization (28) & 0.020 & $\begin{array}{l}\text { Beta } \\
(97.970 \\
4776.154)\end{array}$ \\
\hline $\begin{array}{l}\text { Losses of QALYs associated with a Covid-19 death (calculated based on } \\
\text { an average age of } 45 \text { years at death, life expectancy of } 80 \text { years, age-- } \\
\text { dependent QALYs of the US general population, and discounting future } \\
\text { values at } 3 \%)(29)\end{array}$ & 18.33 & $\begin{array}{l}\text { Normal } \\
(18.33 \\
1.83)\end{array}$ \\
\hline \multicolumn{3}{|c|}{$\begin{array}{l}\text { iD 50: infectious dose 50; Cl: confidence interval; PFU: plaque forming unit; } \mathrm{ACH} \text { : air changes per hour; } \\
\text { HEPA: High Efficiency Particulate Air; CFM: cubic feet per minute (to measure airflow); QALY: quality } \\
\text { adjusted life year. }\end{array}$} \\
\hline
\end{tabular}

Health-related quality of life: We modeled losses of QALYs associated with a Covid-19 symptomatic infection and Covid-19 hospitalization (28). A QALY is a metric capturing both longevity and healthrelated quality of life (HRQL). A QALY can be conceptualized as a year of life lived in perfect health and is 
calculated as the product of the life years remaining and the HRQL score. We also modeled changes in QALYs for the proportion of infected individuals who suffer from long-haul Covid-19 symptoms (28). Finally, we modeled losses of QALYs associated with a Covid-19 premature death (29). We discounted future values at $3 \%(14,17)$.

Analysis: We compared two interventions: 1) no improvement in the baseline ventilation rate of $0.8 \mathrm{ACH}$ ('status quo'), and 2) improving the room ventilation rate to $12 \mathrm{ACH}$. Our mathematical model was probabilistic and was developed in a Monte Carlo simulation of 1,000 iterations, with each iteration randomly drawing from probability distributions of the input parameters. Table 2 shows the model inputs along with their probability distribution.

We performed our analyses for different conditions defined by the mean year-round prevalence of actively infectious cases in the surrounding communities where the restaurant is located and the proportion of patrons that are vaccinated. For the base case model, we assumed a $1 \%$ mean year-round prevalence of actively infectious cases in the surrounding community and a $50 \%$ full-vaccination rate among customers sitting in the restaurant. We modeled the random daily incidence rate from a normal distribution and summed the daily incidence rates over the past 12 days to obtain the daily prevalence of actively infectious cases. This assumes an average of 12 days of infectiousness for an exposed individual beginning 2 days prior to symptom onset (for symptomatic cases) plus 10 days following the initial symptom onset $(30,31)$.

For the best-case scenario (minimum number of infections), we assumed a year-round prevalence of actively infectious cases of $0.1 \%$ in the surrounding community and a $70 \%$ full-vaccination rate among customers sitting in the restaurant.

For the worst-case scenario (maximum number of infections), we assumed a year-round prevalence of actively infectious cases of $2 \%$ in the surrounding community and a $0 \%$ full-vaccination rate among customers sitting in the restaurant.

The time horizon of the model was one year. The outcomes of the model were incremental direct and indirect costs, infections averted, QALYs gained, and ICER for improving the ventilation rate. We also conducted one-way sensitivity analyses over all core input parameters of the model to measure the robustness of model outcomes against changes in these parameters.

\section{Results}

Base-case scenario $(0.1 \%$ prevalence of disease in the surrounding community where the restaurant is located and $50 \%$ full-vaccination rate among of restaurant customers). Improving the room ventilation rate to $12 \mathrm{ACH}$ was associated with 33 infections averted in the standardized restaurant $(95 \%$ credible interval [Crl]: 18,50) over one year. This produced an incremental cost savings of $-\$ 97,467(95 \% \mathrm{Crl}$ : $-\$ 156,760,-\$ 50,877)$, and 0.84 (95\% Crl: $0.46,1.40)$ incremental QALYs gained. Table 3 shows the complete results. 
Table 3

Model outcomes including infections averted, incremental costs, incremental QALYs, and incremental cost-effectiveness ratio for upgrading the room ventilation rate from 0.8 to $12 \mathrm{ACH}$. The model outcomes are calculated for the base-case scenario (mean year-round prevalence of $1 \%$ in the surrounding community where the restaurant is located and when $50 \%$ of the customers are vaccinated), best-case scenario (mean year-round prevalence of $0.1 \%$ in the surrounding community where the restaurant is located and when $70 \%$ of the restaurant customers are vaccinated), and worst-case scenario (mean yearround prevalence of $2 \%$ in the surrounding community where the restaurant is located and when no customer is vaccinated).

\begin{tabular}{|c|c|c|c|c|c|c|}
\hline & $\begin{array}{l}\text { Airborne } \\
\text { infections } \\
\text { averted } \\
\text { Mean } \\
\text { (95\% } \\
\text { Credible } \\
\text { interval) }\end{array}$ & $\begin{array}{l}\text { Net Cost } \\
\text { (\$) } \\
\text { Mean } \\
\text { (95\% } \\
\text { Credible } \\
\text { interval) }\end{array}$ & $\begin{array}{l}\text { Incremental } \\
\text { cost (\$) } \\
\text { Mean (95\% } \\
\text { Credible } \\
\text { interval) }\end{array}$ & $\begin{array}{l}\text { Losses } \\
\text { of } \\
\text { QALYs } \\
\text { Mean } \\
\text { (95\% } \\
\text { Credible } \\
\text { interval) }\end{array}$ & $\begin{array}{l}\text { Incremental } \\
\text { QALYs* } \\
\text { gained } \\
\text { Mean (95\% } \\
\text { Credible } \\
\text { interval) }\end{array}$ & ICER† \\
\hline $\begin{array}{l}\text { Base-case } \\
\text { scenario } \\
(1 \% \\
\text { prevalence } \\
\text { of disease } \\
\text { in the } \\
\text { surrounding } \\
\text { community } \\
\text { where the } \\
\text { restaurant i } \\
\text { located and } \\
\text { when } 50 \% \\
\text { of the } \\
\text { customers } \\
\text { are } \\
\text { vaccinated) }\end{array}$ & & & & & & \\
\hline $\begin{array}{l}\text { Room } \\
\text { ventilation } \\
\text { rate of } 0.8 \\
\mathrm{ACH}\end{array}$ & & $\begin{array}{l}\$ 120,039 \\
(\$ 65,702 \\
\$ 190.267)\end{array}$ & & $\begin{array}{l}1.00 \\
(0.54 \\
1.67)\end{array}$ & & \\
\hline $\begin{array}{l}\text { Improve } \\
\text { room } \\
\text { ventilation } \\
\text { rate to } 12 \\
\text { ACH }\end{array}$ & $\begin{array}{l}33(18, \\
50)\end{array}$ & $\begin{array}{l}\$ 22,573 \\
(\$ 13,867, \\
\$ 33,408)\end{array}$ & $\begin{array}{l}-\$ 97,467 \\
(-\$ 156,760, \\
-\$ 50,877)\end{array}$ & $\begin{array}{l}0.16 \\
(0.09 \\
0.26)\end{array}$ & $\begin{array}{l}0.84(0.46 \\
1.40)\end{array}$ & $\begin{array}{l}-\$ 115,526 / \text { QALY } \\
\text { gained (cost- } \\
\text { saving) }\end{array}$ \\
\hline
\end{tabular}

ICER: incremental cost-effectiveness ratio; QALY: quality adjusted life year; ACH: air changes per hour. Negative ICERs in this table represent a cost-saving scenario, meaning the comparator intervention saves money and improves health.

*Quality-adjusted life years, which is equal to the product of the number of years of life gained and the health-related quality of life score.

†The incremental cost-effectiveness ratio (ICER) is equal to the incremental cost divided by the incremental QALYs gained.

\pm Air exchanges per hour. In this iteration of the model 0.8 is used as the baseline. 


\begin{tabular}{|c|c|c|c|c|c|c|}
\hline & $\begin{array}{l}\text { Airborne } \\
\text { infections } \\
\text { averted } \\
\text { Mean } \\
\text { (95\% } \\
\text { Credible } \\
\text { interval) }\end{array}$ & $\begin{array}{l}\text { Net Cost } \\
\text { (\$) } \\
\text { Mean } \\
\text { (95\% } \\
\text { Credible } \\
\text { interval) }\end{array}$ & $\begin{array}{l}\text { Incremental } \\
\text { cost (\$) } \\
\text { Mean (95\% } \\
\text { Credible } \\
\text { interval) }\end{array}$ & $\begin{array}{l}\text { Losses } \\
\text { of } \\
\text { QALYs } \\
\text { Mean } \\
\text { ( } 95 \% \\
\text { Credible } \\
\text { interval) }\end{array}$ & $\begin{array}{l}\text { Incremental } \\
\text { QALYs* } \\
\text { gained } \\
\\
\text { Mean (95\% } \\
\text { Credible } \\
\text { interval) }\end{array}$ & ICERT \\
\hline $\begin{array}{l}\text { Best-case } \\
\text { scenario } \\
(0.1 \% \\
\text { prevalence } \\
\text { of disease } \\
\text { in the } \\
\text { surrounding } \\
\text { community } \\
\text { where the } \\
\text { restaurant is } \\
\text { located and } \\
\text { when } 70 \% \\
\text { of the } \\
\text { restaurant } \\
\text { customers } \\
\text { are } \\
\text { vaccinated) }\end{array}$ & & & & & & \\
\hline $\begin{array}{l}\text { Room } \\
\text { ventilation } \\
\text { rate of } 0.8 \\
\mathrm{ACH}\end{array}$ & & $\begin{array}{l}\$ 9,472 \\
(\$ 5,189 \\
\$ 15,065)\end{array}$ & & $\begin{array}{l}0.08 \\
(0.04 \\
0.13)\end{array}$ & & \\
\hline $\begin{array}{l}\text { Improve } \\
\text { room } \\
\text { ventilation } \\
\text { rate to } 12 \\
\text { ACH }\end{array}$ & $3(2,4)$ & $\begin{array}{l}\$ 5,225 \\
(\$ 4,226 \\
\$ 6,416)\end{array}$ & $\begin{array}{l}\$ 4,247 \\
(-\$ 515 \\
-\$ 9,006)\end{array}$ & $\begin{array}{l}0.01 \\
(0.007 \\
0.02)\end{array}$ & $\begin{array}{l}0.07(0.04 \\
0.11)\end{array}$ & $\begin{array}{l}\text {-\$61,684/QALY } \\
\text { gained (cost- } \\
\text { saving) }\end{array}$ \\
\hline
\end{tabular}

ICER: incremental cost-effectiveness ratio; QALY: quality adjusted life year; $\mathrm{ACH}$ : air changes per hour. Negative ICERs in this table represent a cost-saving scenario, meaning the comparator intervention saves money and improves health.

*Quality-adjusted life years, which is equal to the product of the number of years of life gained and the health-related quality of life score.

†The incremental cost-effectiveness ratio (ICER) is equal to the incremental cost divided by the incremental QALYs gained.

\pm Air exchanges per hour. In this iteration of the model 0.8 is used as the baseline. 


\begin{tabular}{|c|c|c|c|c|c|c|}
\hline & $\begin{array}{l}\text { Airborne } \\
\text { infections } \\
\text { averted } \\
\text { Mean } \\
\text { (95\% } \\
\text { Credible } \\
\text { interval) }\end{array}$ & $\begin{array}{l}\text { Net Cost } \\
(\$) \\
\text { Mean } \\
\text { (95\% } \\
\text { Credible } \\
\text { interval) }\end{array}$ & $\begin{array}{l}\text { Incremental } \\
\text { cost (\$) } \\
\text { Mean (95\% } \\
\text { Credible } \\
\text { interval) }\end{array}$ & $\begin{array}{l}\text { Losses } \\
\text { of } \\
\text { QALYs } \\
\text { Mean } \\
\text { (95\% } \\
\text { Credible } \\
\text { interval) }\end{array}$ & $\begin{array}{l}\text { Incremental } \\
\text { QALYs } \\
\text { gained } \\
\text { Mean (95\% } \\
\text { Credible } \\
\text { interval) }\end{array}$ & ICERT \\
\hline \multicolumn{7}{|l|}{$\begin{array}{l}\text { Worst-case } \\
\text { scenario } \\
\text { ( } 2 \% \\
\text { prevalence } \\
\text { of disease } \\
\text { in the } \\
\text { surrounding } \\
\text { community } \\
\text { where the } \\
\text { restaurant is } \\
\text { located and } \\
\text { when no } \\
\text { customer is } \\
\text { vaccinated) }\end{array}$} \\
\hline $\begin{array}{l}\text { Room } \\
\text { ventilation } \\
\text { rate of } 0.8 \\
\mathrm{ACH}^{ \pm}\end{array}$ & & $\begin{array}{l}\$ 367,212 \\
(\$ 199,224, \\
\$ 593,313)\end{array}$ & & $\begin{array}{l}2.93 \\
(1.61 \\
4.86)\end{array}$ & & \\
\hline $\begin{array}{l}\text { Improve } \\
\text { room } \\
\text { ventilation } \\
\text { rate to } 12 \\
\text { ACH }\end{array}$ & $\begin{array}{l}91(51, \\
143)\end{array}$ & $\begin{array}{l}\$ 61,373 \\
(\$ 35,080 \\
\$ 96,635)\end{array}$ & $\begin{array}{l}-\$ 305,840 \\
(-\$ 496,461 \\
-\$ 164,324)\end{array}$ & $\begin{array}{l}0.46 \\
(0.25 \\
0.76)\end{array}$ & $\begin{array}{l}2.47(1.36, \\
4.10)\end{array}$ & $\begin{array}{l}-\$ 123,862 / \text { QALY } \\
\text { gained (cost- } \\
\text { saving) }\end{array}$ \\
\hline \multicolumn{7}{|c|}{$\begin{array}{l}\text { ICER: incremental cost-effectiveness ratio; QALY: quality adjusted life year; ACH: air changes per hour. } \\
\text { Negative ICERs in this table represent a cost-saving scenario, meaning the comparator intervention } \\
\text { saves money and improves health. }\end{array}$} \\
\hline \multicolumn{7}{|c|}{$\begin{array}{l}{ }^{*} \text { Quality-adjusted life years, which is equal to the product of the number of years of life gained and } \\
\text { the health-related quality of life score. }\end{array}$} \\
\hline \multicolumn{7}{|c|}{$\begin{array}{l}\text { TThe incremental cost-effectiveness ratio (ICER) is equal to the incremental cost divided by the } \\
\text { incremental QALYs gained. }\end{array}$} \\
\hline
\end{tabular}

The best-case scenario $(0.1 \%$ prevalence of disease in the surrounding community where the restaurant is located and $70 \%$ full-vaccination rate among restaurant customers). This scenario reflects conditions far better than were observed for the United States for the pandemic through October of 2021. It was associated with cost savings of $-\$ 4,247(95 \% \mathrm{Crl}:-\$ 515,-\$ 9,006)$ and $0.07(95 \% \mathrm{Crl}: 0.04,0.11)$ QALYs gained. 
The worst-case scenario ( $2 \%$ prevalence of disease in the surrounding community where the restaurant is located and $0 \%$ full-vaccination rate among restaurant customers). In this scenario, improving air handling systems increased QALYs and saved money with 91 (95\% Crl: 51, 143) infections averted, incremental costs of $-\$ 305,840$ (95\% Crl: $-\$ 496,461,-\$ 164,324)$, and incremental QALYs gained of 2.47 (95\% Crl: $1.36,4.10)$.

Figure 1 shows the results of the one-way sensitivity analyses. In all sensitivity analyses, improving the air handling system was cost-saving in the base-case scenario, meaning standalone air filtration units reduced airborne infections, increased QALYs gained, and resulted in savings for the commercial establishment.

Figure 2 shows the probabilistic distribution of differential costs and differential QALYs of improving air handling system across all Monte Carlo simulation runs. For the base-case and worst-case scenarios, in all the simulation runs, improving the air handling system resulted in cost savings and QALYs gained. Under the best-case scenario, $99 \%$ of the simulations resulted in cost savings and QALYs gained, and all analyses produced an ICER $<\$ 50,000 /$ QALY gained.

\section{Discussion}

In this study, we evaluated the cost-effectiveness of improving ventilation in commercial indoor spaces as a method of preventing the transmission of SARS-CoV-2. We built our probabilistic model using a Monte Carlo simulation so that the average model outcomes account for uncertainties and represent different ranges of variability in model input parameters and assumptions. Our probabilistic analyses showed that under all scenarios-even when the mean year-round prevalence of actively infectious cases was as low as $0.1 \%$ and $70 \%$ of the restaurant's patrons were fully vaccinated-improving the ventilation rate of the indoor spaces by standalone air-filtration units would result in cost savings and QALYs gained.

There is a growing body of research modeling airborne transmission of SARS-CoV-2 via aerosolized particles in indoor spaces $(18,32-36)$. A recent study suggested that inhalation of aerosolized SARSCOV-2 particles is deemed to be the main source of transmission of the virus among the general population (33) and provided a theoretical model to quantify a safety cap for the number of occupants and the amount of time they should spend in an indoor space to reduce the airborne transmission of the virus. Other studies support the transmission of Covid-19 by aerosols (34), and suggest that indoor ventilation can significantly reduce infection (36). However, the cost-effectiveness of such airborne preventive measures in a poorly ventilated indoor space is not clear, and hinges upon multiple factors. These include the community prevalence of disease, number occupants and their time spent in the room, size of the room, and the proportion of occupants that are fully vaccinated. Our model allows for adjustable model input parameters that can be customized by the user using the accompanying online application (https://openupuniversities.shinyapps.io/Airborne_Transmission_Covid19/).

The underpinning risk transmission model has been previously vetted (18). However, we updated the parameter representing the number of viral RNA copies/ $\mathrm{ml}$ in the sputum of the infected individual 
according to emerging data from the current, predominant strain of SARS-CoV-2 Delta variant, which suggests that the number of copies for the Delta variant is 1,000 times greater than the original strains (21).

Our study was limited in several ways. First, we modeled the hospitalization rate and mortality rate only as a function of age in line with the previous studies $(28,37)$. In theory, however, hospitalization and mortality rates are also functions of other patient characteristics, such as gender, race, comorbidity, and socioeconomic status. Because the intent of our analysis was improving ventilation, we only modeled infections through inhalation of airborne, aerosolized viruses that may accumulate indoors, and we did not model infections via other pathways such as fomite transmission or inhalation of small and large droplets shortly after they are exhaled. To the extent that they do not equally affect both the competing intervention arms (i.e., air handling systems without and with improving the ventilation rate to $12 \mathrm{ACH}$ ), the air handling systems would likely reduce fomite transmission. This would result in an underestimate of cost savings and QALYs gained. While our model does not provide data across different variants of SARS-CoV-2 due to natural limitations in data availability, we updated the model parameters to represent the current dominant SARS-CoV-2 strain, the Delta variant. As more data becomes available for the Delta variant or as new variants of the virus emerge, our model parameters can easily be updated using our online web application and open source code. Finally, in our model, we assumed a homogeneity of airborne, long-range infection across all patrons.

\section{Conclusions}

Even in the absence of SARS-CoV-2, poor ventilation systems in commercial spaces pose significant public health risks (38). As the Covid-19 turns into an endemic disease, and as new pathogens emerge, it is critically important to set standards for ventilation of commercial spaces, even when they are in older buildings. In doing so, regulators must walk a fine line between setting standards that are too stringent to be economically viable for small business owners and the safety of the patrons of those establishments. We found that these systems are affordable from a governmental regulatory standpoint for most businesses. Moreover, as competition increases for novel air filtration systems, these systems are likely to fall in cost and increase in efficacy.

\section{Declarations}

Ethics approval and consent to participate: This study was modeling and no human subject was involved.

\section{Consent for publication: N/A}

Availability of data and martials: We build an accompanying online dashboard for the model. Other data will be available upon request from the authors. 
Funding: This study did not have funding.

Competing interests: Authors declared no conflict of interest.

Authors' contributions: ZZ developed the study idea, designed the study, performed the statistical analysis and programming, and wrote the first draft of the manuscript; PMDO and SG helped with the methodology, implementation, and interpretation of findings. PAM helped with the study design, implementation, and interpretation of findings. CE helped with data collection. All authors contributed to the writing.

\section{References}

1. Coleman KK, Tay DJW, Sen Tan K, Ong SWX, Son TT, Koh MH, et al. Viral Load of SARS-CoV-2 in Respiratory Aerosols Emitted by COVID-19 Patients while Breathing, Talking, and Singing. Clin Infect Dis [Internet]. 2021 Aug 6 [cited 2021 Aug 23];(ciab691). Available from: https://doi.org/10.1093/cid/ciab691

2. Lednicky JA, Lauzardo M, Fan ZH, Jutla A, Tilly TB, Gangwar M, et al. Viable SARS-CoV-2 in the air of a hospital room with COVID-19 patients. Int J Infect Dis. 2020 Nov 1;100:476-82.

3. Li Y, Leung GM, Tang JW, Yang X, Chao CYH, Lin JZ, et al. Role of ventilation in airborne transmission of infectious agents in the built environment - a multidisciplinary systematic review. Indoor Air. 2007 Feb;17(1):2-18.

4. Zhang R, Li Y, Zhang AL, Wang Y, Molina MJ. Identifying airborne transmission as the dominant route for the spread of COVID-19. Proc Natl Acad Sci. 2020 Jun 30;117(26):14857-63.

5. Fennelly KP. Particle sizes of infectious aerosols: implications for infection control. Lancet Respir Med. 2020 Sep 1;8(9):914-24.

6. Fisk WJ, Rosenfeld AH. Estimates of Improved Productivity and Health from Better Indoor Environments. Indoor Air. 1997;7(3):158-72.

7. Centers for Disease Control and Prevention. Ventilation in buildings [Internet]. Centers for Disease Control and Prevention. 2020 [cited 2021 Aug 9]. Available from: https://www.cdc.gov/coronavirus/2019-ncov/community/ventilation.html

8. World Health Organization. Roadmap to improve and ensure good indoor ventilation in the context of COVID-19 [Internet]. [cited 2021 Aug 9]. Available from: https://www.who.int/publications-detailredirect/9789240021280

9. Ventilation of indoor spaces to stop the spread of coronavirus (COVID-19) [Internet]. GOV.UK. [cited 2021 Aug 9]. Available from: https://www.gov.uk/government/publications/covid-19-ventilation-ofindoor-spaces-to-stop-the-spread-of-coronavirus/ventilation-of-indoor-spaces-to-stop-the-spread-ofcoronavirus-covid-19

10. Centers for Disease Control and Prevention. Guidelines for Environmental Infection Control in HealthCare Facilities [Internet]. 2019 [cited 2021 Aug 28]. Available from: 
https://www.cdc.gov/infectioncontrol/guidelines/environmental/appendix/air.html

11. Environmental Protection Agency. Air cleaning devices that use bipolar ionization, including portable air cleaners and in-duct air cleaners used in HVAC systems [Internet]. [cited 2021 Mar 25]. Available from: https://www.epa.gov/coronavirus/air-cleaners-hvac-filters-and-coronavirus-covid-19

12. Lerner AM, Folkers GK, Fauci AS. Preventing the Spread of SARS-CoV-2 With Masks and Other "Lowtech" Interventions. JAMA. 2020 Nov 17;324(19):1935-6.

13. Lewis D. Why indoor spaces are still prime COVID hotspots. Nature. 2021 Mar 30;592(7852):22-5.

14. Neumann PJ, Sanders GD, Russell LB, Siegel JE, Ganiats TG. Cost-Effectiveness in Health and Medicine. Second Edition, New to this Edition: Oxford, New York: Oxford University Press; 2016. 536 p.

15. Muennig PA, Bounthavong M. Cost-effectiveness analysis in health: a practical approach. John Wiley \& Sons; 2016.

16. Wonderling D, Sawyer L, Fenu E, Lovibond K, Laramée P. National Clinical Guideline Centre costeffectiveness assessment for the National Institute for Health and Clinical Excellence. Ann Intern Med. 2011 Jun 7;154(11):758-65.

17. Sanders GD, Neumann PJ, Basu A, Brock DW, Feeny D, Krahn M, et al. Recommendations for Conduct, Methodological Practices, and Reporting of Cost-effectiveness Analyses: Second Panel on CostEffectiveness in Health and Medicine. JAMA. 2016 Sep 13;316(10):1093-103.

18. de Oliveira PM, Mesquita LCC, Gkantonas S, Giusti A, Mastorakos E. Evolution of spray and aerosol from respiratory releases: theoretical estimates for insight on viral transmission. Proc R Soc Math Phys Eng Sci. 2021 Jan 27;477(2245):20200584.

19. Gkantonas S, Zabotti D, Mesquita L, Mastorakos E, de Oliveira P. Airborne.cam [Internet]. [cited 2021 Jul 20]. Available from: https://airborne.cam/

20. Wölfel R, Corman VM, Guggemos W, Seilmaier M, Zange S, Müller MA, et al. Virological assessment of hospitalized patients with COVID-2019. Nature. 2020 May;581(7809):465-9.

21. Li B, Deng A, Li K, Hu Y, Li Z, Xiong Q, et al. Viral infection and transmission in a large well-traced outbreak caused by the Delta SARS-CoV-2 variant [Internet]. 2021 Jul [cited 2021 Aug 11] p. 2021.07.07.21260122. Available from:

https://www.medrxiv.org/content/10.1101/2021.07.07.21260122v1

22. van Doremalen N, Bushmaker T, Morris DH, Holbrook MG, Gamble A, Williamson BN, et al. Aerosol and Surface Stability of SARS-CoV-2 as Compared with SARS-CoV-1. N Engl J Med. 2020 Apr 16;382(16):1564-7.

23. Gupta JK, Lin C-H, Chen Q. Characterizing exhaled airflow from breathing and talking. Indoor Air. 2010 Feb;20(1):31-9.

24. Watanabe T, Bartrand TA, Weir MH, Omura T, Haas CN. Development of a Dose-Response Model for SARS Coronavirus. Risk Anal. 2010;30(7):1129-38. 
25. Bartsch SM, Ferguson MC, McKinnell JA, O'Shea KJ, Wedlock PT, Siegmund SS, et al. The Potential Health Care Costs And Resource Use Associated With COVID-19 In The United States. Health Aff Proj Hope. 2020 Jun;39(6):927-35.

26. Avalere. COVID-19 Hospitalizations Projected to Cost up to \$17B in US in 2020 [Internet]. [cited 2020 Aug 6]. Available from: https://avalere.com/insights/covid-19-hospitalizations-projected-to-cost-upto-17b-in-us-in-2020

27. May 2020 State Occupational Employment and Wage Estimates [Internet]. [cited 2021 Aug 23]. Available from: https://www.bls.gov/oes/2020/may/oessrcst.htm

28. Sandmann FG, Davies NG, Vassall A, Edmunds WJ, Jit M, Sun FY, et al. The potential health and economic value of SARS-CoV-2 vaccination alongside physical distancing in the UK: a transmission model-based future scenario analysis and economic evaluation. Lancet Infect Dis. $2021 \mathrm{Jul}$ 1;21(7):962-74.

29. Briggs A. Moving beyond "lives saved" from COVID-19 [Internet]. [cited 2021 Jul 20]. Available from: https://avalonecon.com/moving-beyond-lives-saved-from-covid-19/

30. CDC. Interim guidance on ending isolation and precautions for adults with COVID-19 [Internet]. Centers for Disease Control and Prevention. 2020 [cited 2021 Aug 11]. Available from: https://www.cdc.gov/coronavirus/2019-ncov/hcp/duration-isolation.html

31. Walsh KA, Spillane S, Comber L, Cardwell K, Harrington P, Connell J, et al. The duration of infectiousness of individuals infected with SARS-CoV-2. J Infect. 2020 Dec;81(6):847-56.

32. Pei G, Rim D, Taylor MI. Effects of Indoor Airflow and Ventilation Strategy on the Airborne Virus Transmission. ASHRAE Trans. 2021 Jan 1;127(1):206-16.

33. Bazant MZ, Bush JWM. A guideline to limit indoor airborne transmission of COVID-19. Proc Natl Acad Sci [Internet]. 2021 Apr 27 [cited 2021 Aug 11];118(17). Available from: https://www.pnas.org/content/118/17/e2018995118

34. Greenhalgh T, Jimenez JL, Prather KA, Tufekci Z, Fisman D, Schooley R. Ten scientific reasons in support of airborne transmission of SARS-CoV-2. The Lancet. 2021 May 1;397(10285):1603-5.

35. National Academies of Sciences, Engineering, and Medicine. Airborne Transmission of SARS-CoV-2: Proceedings of a Workshop-in Brief [Internet]. National Academy of Sciences; 2020 [cited 2021 Aug 11]. Available from: https://www.nap.edu/read/25958/chapter/1

36. Allen JG, Ibrahim AM. Indoor Air Changes and Potential Implications for SARS-CoV-2 Transmission. JAMA. 2021 May 25;325(20):2112-3.

37. Davies NG, Kucharski AJ, Eggo RM, Gimma A, Edmunds WJ, Jombart T, et al. Effects of nonpharmaceutical interventions on COVID-19 cases, deaths, and demand for hospital services in the UK: a modelling study. Lancet Public Health. 2020 Jul 1;5(7):e375-85.

38. Sundell J, Levin H, Nazaroff WW, Cain WS, Fisk WJ, Grimsrud DT, et al. Ventilation rates and health: multidisciplinary review of the scientific literature. Indoor Air. 2011 Jun;21(3):191-204.

39. Alene M, Yismaw L, Assemie MA, Ketema DB, Mengist B, Kassie B, et al. Magnitude of asymptomatic COVID-19 cases throughout the course of infection: A systematic review and meta-analysis. PLOS 
ONE. 2021 Mar 23;16(3):e0249090.

40. Sudre $\mathrm{CH}$, Murray B, Varsavsky T, Graham MS, Penfold RS, Bowyer RC, et al. Attributes and predictors of long COVID. Nat Med. 2021 Apr;27(4):626-31.

41. Lopez Bernal J, Andrews N, Gower C, Gallagher E, Simmons R, Thelwall S, et al. Effectiveness of Covid-19 Vaccines against the B.1.617.2 (Delta) Variant. N Engl J Med. 2021 Aug 12;385(7):585-94.

42. Alen BreatheSmart 75i True HEPA Air Purifier [Internet]. Alen. [cited 2021 Aug 18]. Available from: https://alen.com/products/alen-breathesmart-75i-air-purifier

\section{Figures}

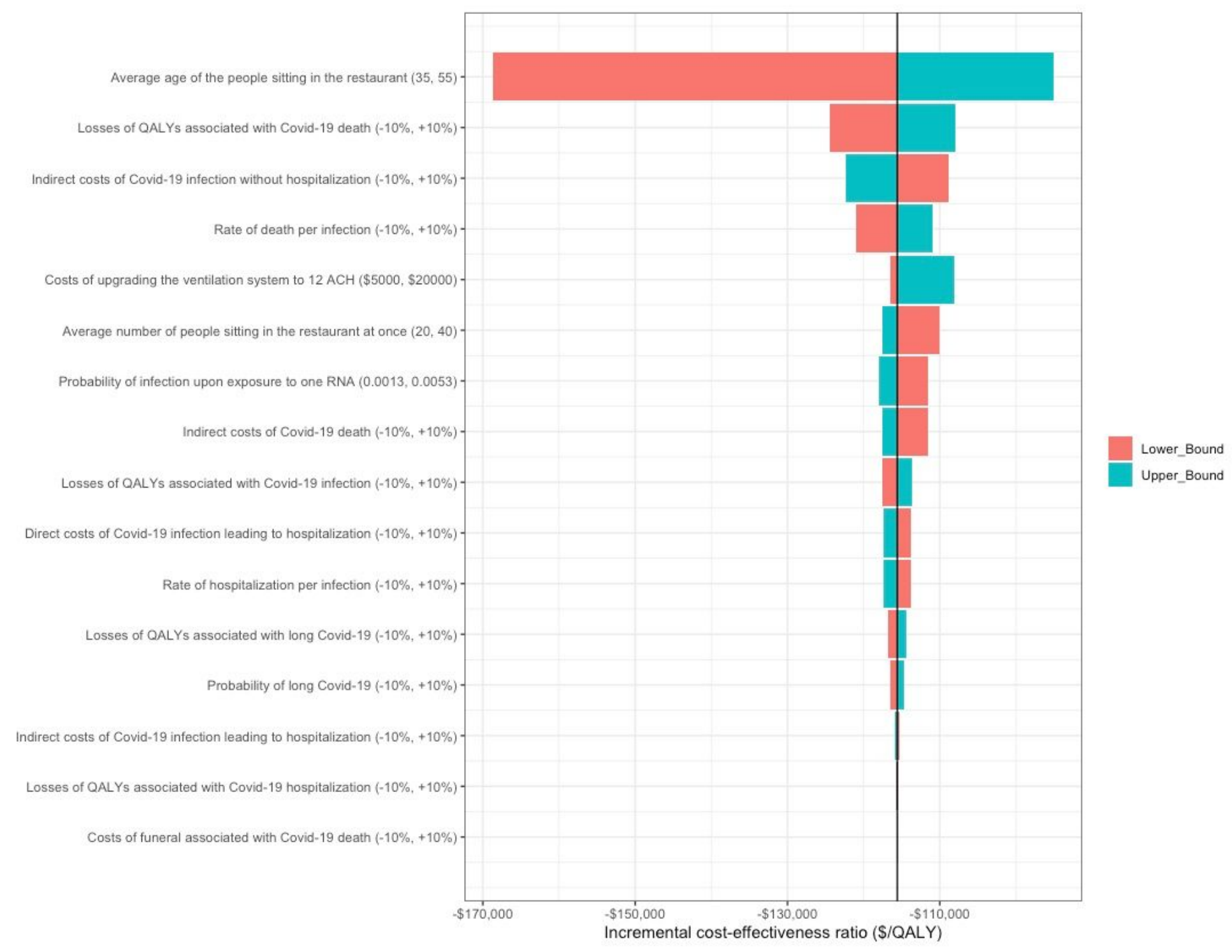

\section{Figure 1}

One-way sensitivity analysis for the core input parameters of the model for evaluating the costeffectiveness of upgrading the ventilation system of a $100 \mathrm{~m} 2$ restaurant space from $0.8 \mathrm{ACH}$ to $12 \mathrm{ACH}$ 
for the base case scenario (mean year-round prevalence of $1 \%$ in the surrounding community where the restaurant is located and when $50 \%$ of the customers are vaccinated). QALYs: quality-adjusted life years; $\mathrm{ACH}$ : air changes per hour. Note in all the sensitivity analyses, improving the ventilation rate to $12 \mathrm{ACH}$ saved money and improved health. Therefore, the negative incremental cost-effectiveness ratios on the $x-$ axis can be interpreted as decreases in costs associated with improving the ventilation rate for one QALY increase.
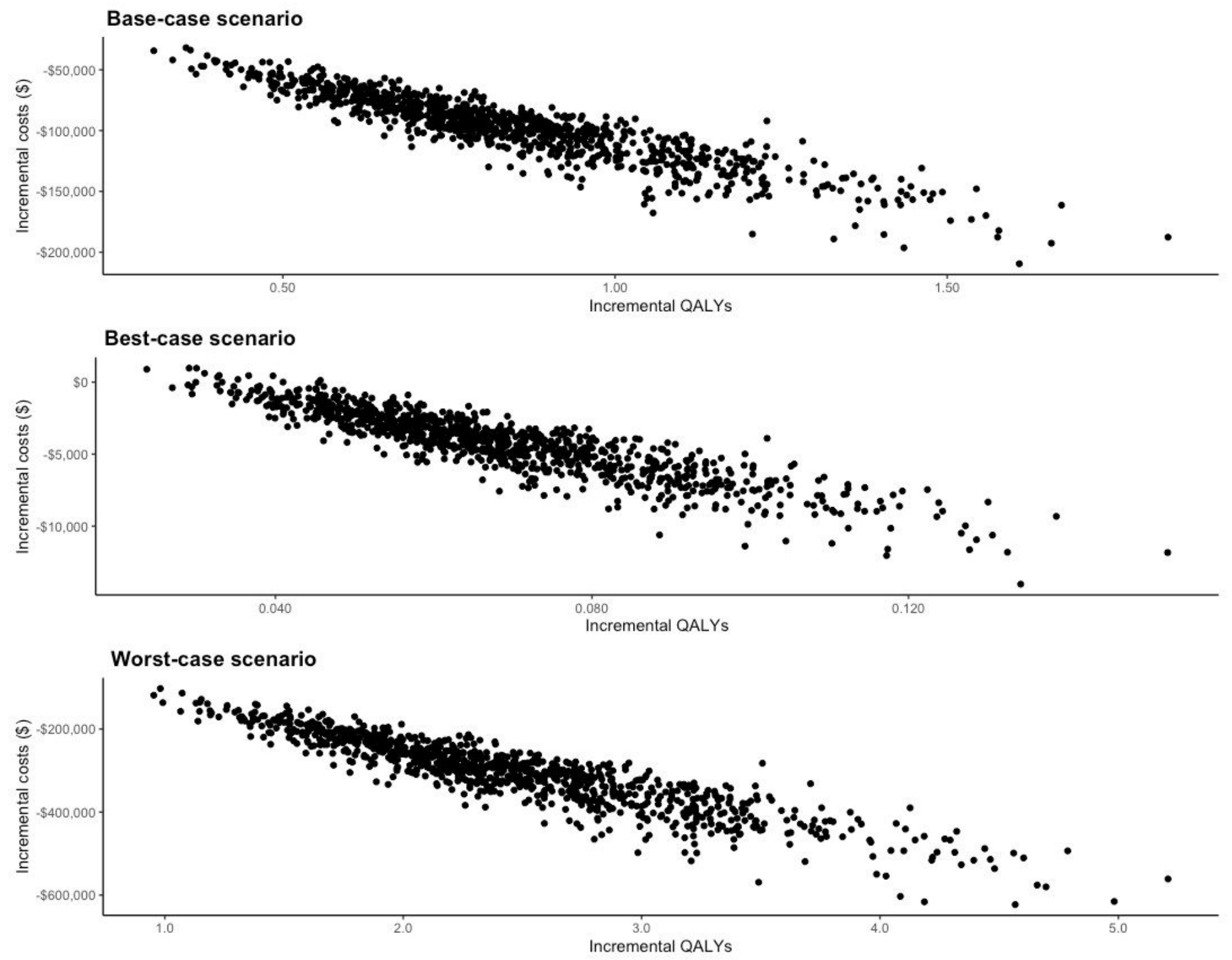

Figure 2

The cost-effectiveness plane representing the incremental costs versus incremental QALYs for upgrading the ventilation system of an exemplary $100 \mathrm{~m} 2$ restaurant space to $12 \mathrm{ACH}$ for: (A) the base-case scenario (mean year-round prevalence of $1 \%$ in the surrounding community where the restaurant is located and when $50 \%$ of the customers are vaccinated); (B) the best-case scenario (mean year-round prevalence of $0.1 \%$ in the surrounding community where the restaurant is located and when $70 \%$ of the restaurant customers are vaccinated); and (C) the worst-case scenario (mean year-round prevalence of $2 \%$ in the surrounding community where the restaurant is located and when no customer is vaccinated). 
The dots in the plot show the probabilistic runs of the Monte Carlo simulation with 1,000 iterations. QALYs: quality-adjusted life years; ACH: air changes per hour. 